\title{
Determination of Level of Serum Iron among Routine Iron Supplemented Pregnant Women Attending Private Clinic in Sulaimani City, Kurdistan-Iraq
}

\author{
Sardar M. Weli'1, Osama H. Shareef ${ }^{2}$, Syamand A. Qadir²* \\ ${ }^{1}$ Department of Nursing, Technical College of Health, Sulaimani Polytechnic University, Sulaimani, Kurdistan Region, Iraq, ${ }^{2}$ Department of \\ Medical Laboratory Science, Technical College of Applied Sciences, Sulaimani Polytechnic University, Sulaymaniyah, Kurdistan Region, Iraq
}

\section{*Corresponding author: \\ Syamand A. Qadir, \\ Department of Medical \\ Laboratory Science, \\ Technical College of \\ Applied Sciences, \\ Sulaimani Polytechnic \\ University, Sulaymaniyah, \\ Kurdistan Region, Iraq. \\ E-mail: syamand.qadir@ \\ spu.edu.iq}

Received: 15 September 2020

Accepted: 28 January 2021

Published: 30 June 2021

\section{DOI}

10.25156/pti.v11n1y2021.pp76-79

\section{A B S T R A C T}

Iron deficiency, with or without anemia, is common in pregnant women and more than half of the anemia's in the world are due to the deficiency of iron in the serum. The aims of this study were to determine the percentage and level of serum iron among iron supplemented pregnant women in different trimesters and in different age groups among supplemented pregnant women in Sulaimani city. This study was carried out in the private clinic in the Sulaimani city-Kurdistan Region of Iraq. The pregnant women were participated and enrolled between the first of December 2018 and first of December 2019. Two hundred and seventy-five healthy and iron supplemented pregnant women were selected randomly and the questionnaire form, which contains information about age of mothers and their gestational age, was filled and serum iron level was measured by COBAS C111 analyzer. The results of this study found that the percentage of iron deficiency among participants was high $33 \%$, $45 \%$, and $52.6 \%$ in the first trimester in different age groups $<25,25-35$, and above 35 years old, respectively. However, in the third trimesters decreased to $12.5 \%, 7.1 \%$, and $3.7 \%$ in $<25$, 25-35, and above 35 years old, respectively. Regarding serum iron levels, the present study found that there were significant differences between ages 25 and 35 with age $<25$ years. However, there was no significant difference between first, second, and third trimesters. This study concludes that the percentage of iron deficiency among supplemented pregnant women was high compared to other cities or other countries. Pregnant women who their ages $<25$ are at risk of serum iron deficiency. On the other hand, pregnancy trimesters had no effects on the serum iron level among supplemented pregnant women.

Keywords: Serum iron; Pregnant women; Supplementation; Trimester

\section{INTRODUCTION}

Iron deficiency is considered as one of the main etiological factors contributed to anemia in pregnant women (Vanderjagt et al., 2007). According to the World Health Organization (WHO), 41.8\% pregnant women were anemic in the worldwide and more than half of this anemia are due to iron deficiency (WHO). Pregnant women become anemic because the physiological demand for iron increased and the inability of the body to meet the required iron level due to nutritional insufficiency, blood diseases such as thalassemia or due to bacterial or parasitic infections that affect intestinal ability to absorb iron from food (Kumar et al., 2014). In addition, plasma volume increases by $6 \%$ in the first trimester, by $29 \%$ at the end of the second trimester, and 48\% (peak expansion) near term in healthy pregnant women (Aguree and Gernand, 2019). Iron deficiency anemia (IDA) during pregnancy is associated with many health problems for mothers such as increased risk for perinatal bleeding and transfusion, placental abruption, and preeclampsia. It is considered as risk factors for many other conditions such as thyroid diseases, cardiac failure, and even death (Juul et al., 2019). In addition, there is a relationship between IDA and a low birth weight infants, motor development, and cognitive functions in infancy (Tran et al., 2013; Ajepe et al., 2020). Maternal IDA is considers a risk factor for infant's iron store. Half of anemic infants were from severe anemic mothers (De Sá et al., 2015; Terefe et al., 2015). To prevent IDA complication for both mothers and child's health, it was strongly recommended for pregnant women to take daily iron supplementation (WHO). The recommendation dose for developing countries for non-anemic women is $60 \mathrm{mg}$ of iron daily; however, this dose can be increased to $120 \mathrm{mg}$ daily for anemic women (Yakoob and Bhutta, 2011). The present study aims to determine the percentage and level of serum iron among iron supplemented pregnant women in different trimesters and in different age groups. 


\section{MATERIALS AND METHODS}

\section{Data Collection}

This study was carried out in the private clinic in the Sulaymaniyah city-Kurdistan Region of Iraq. The pregnant women were enrolled between the first of December 2018 and first of December 2019. Two hundred and seventyfive healthy and daily iron supplemented pregnant women were selected randomly and the questionnaire form, which contains information about age of mothers and their gestational age, was filled.

\section{Blood Sample Collections}

Blood was collected directly from median cubital vein using disposable syringes. Blood specimens were centrifuged at $2500 \mathrm{rpm}$ for $5 \mathrm{~min}$, and then serum samples were stored in freezer at $-20^{\circ} \mathrm{C}$ till analysis.

\section{Serum Sample Analysis}

Serum samples were used to measure the iron level using COBAS C111 analyzer in the Bawk private clinic. The COBAS C111 is a fully automated, softwarecontrolled system. The color intensity can be measured photometrically and is directly proportional to the iron concentration.

\section{Data Analysis}

The data were transferred to the SPSS Software version (IBM SPSS Statistics 20). The results were presented as mean \pm SE. The data were analyzed by one-way ANOVA. Comparisons within serum iron levels, trimesters, and ages were performed LSD test and Chi-square test. The significance level was set at 0.05 .

\section{RESULTS}

Two hundred seventy-five supplemented-pregnant women were checked their serum iron levels. They were separated into three age groups according to their ages $(<25$ years, 25-35 years, and above 35 years) and trimesters. The percentages of the lowered serum iron level among participants are shown in Table 1.

Table 2 showed mean \pm SE of iron level in different ages and in different trimesters. The mean $\pm \mathrm{SE}$ of serum iron in maternal age $<25$ years, $25-35$, and above 35 was 56.41 $\pm 2.43,70.56 \pm 2.77$, and $64.27 \pm 2.78$, respectively. In addition, the mean \pm SE of serum iron in first, second, and third trimesters was $67.28 \pm 3.17,65.40 \pm 2.90$, and $64.69 \pm 2.97$, respectively.

Table 3 showed the mean \pm SD of serum iron in different ages according to trimesters. There were no significant differences between different ages according to trimesters.
Table 1: It shows the number of supplemented-pregnant women with percentage of lowered serum iron level among participants

\begin{tabular}{lcccccc}
\hline \begin{tabular}{l} 
Trimesters $\begin{array}{l}\text { of } \\
\text { pregnancy }\end{array}$ \\
\cline { 2 - 7 }
\end{tabular} & $\begin{array}{c}\text { No. of } \\
\text { participants } \\
<25\end{array}$ years (\%) & $\begin{array}{c}\text { Mother ages } \\
\text { participants } \\
\text { 25-35 years (\%) }\end{array}$ & $\begin{array}{c}\text { No. of } \\
\text { participants More } \\
\text { than }\end{array}$ \\
\hline First & 7 & 35 & 26 & 57.7 & 6 & 31.5 \\
Second & 17 & 85 & 32 & 56.1 & 8 & 38.09 \\
Third & 12 & 50 & 16 & 38.01 & 15 & 55.5 \\
\hline
\end{tabular}

Table 2: It shows mean \pm SE of mean for serum iron levels (serum iron $\mu \mathrm{g} / \mathrm{dl}$ ) in different trimesters and ages of pregnancy with significant differences between them

\begin{tabular}{|c|c|c|c|c|c|c|}
\hline \multicolumn{7}{|c|}{ Iron *Age } \\
\hline Age (year) & Mean & $n$ & Minimum & Maximum & $\begin{array}{l}\text { Std. Error } \\
\text { of Mean }\end{array}$ & r P-value \\
\hline$<25$ & 56.41 & 64 & 27.90 & 99.30 & 2.43 & 0.004 Sig. \\
\hline 25-35 & 70.56 & 144 & 32.40 & 179.00 & 2.77 & \\
\hline Above 35 & 64.27 & 67 & 37.80 & 121.00 & 2.78 & \\
\hline \multicolumn{7}{|c|}{ Iron *Trimester } \\
\hline First & 67.28 & 84 & 34.20 & 179.00 & 3.17 & 0.829 Ns. \\
\hline Second & 65.40 & 98 & 27.90 & 151.20 & 2.90 & \\
\hline Third & 64.69 & 93 & 29.50 & 173.40 & 2.97 & \\
\hline
\end{tabular}

Table 3: It shows the mean $\pm S D$ of mean for serum iron levels (serum iron $\mu \mathrm{g} / \mathrm{dl}$ ) in different trimesters for different ages

\begin{tabular}{lllll}
\hline \multicolumn{4}{c}{ Dependent variable: Iron } & \\
\hline$<25$ & Trimester & Mean & Std. Deviation & $\boldsymbol{n}$ \\
& First & 61.59 & 19.75 & 20 \\
& Second & 50.99 & 22.79 & 20 \\
& Third & 56.62 & 15.58 & 24 \\
25-35 & Total & 56.41 & 19.51 & 64 \\
& First & 71.89 & 36.43 & 45 \\
& Second & 69.70 & 29.69 & 57 \\
& Third & 70.30 & 35.27 & 42 \\
Above 35 & Total & 70.56 & 33.34 & 144 \\
& First & 62.35 & 11.37 & 19 \\
& Second & 67.46 & 28.09 & 21 \\
& Third & 63.14 & 24.75 & 27 \\
Total & Total & 64.27 & 22.81 & 67 \\
& First & 67.28 & 29.08 & 84 \\
& Second & 65.40 & 28.78 & 98 \\
& Third & 64.69 & 28.64 & 93 \\
& Total & 65.73 & 28.74 & 275 \\
\hline
\end{tabular}

However, there is a significant different between serum iron levels in different age groups, the data are shown in Table 4.

\section{DISCUSSION}

Serum Iron deficiency is the most common cause of nutritional or micronutrients deficiency among pregnant women particularly in the developing countries (Kumar et al., 2014; Peña-Rosas and Viteri, 2009). Fortunately, routine iron supplementation is a vital mean in improving the global problem of iron deficiency in pregnancy and 
Table 4: Dependent variable (serum iron $\mu \mathrm{g} / \mathrm{dl}$ ) compared to both age and trimester

\begin{tabular}{llll}
\hline \multicolumn{4}{c}{ Multiple comparisons } \\
\hline Age & Aependent variable: Iron & \\
\hline$<25$ & $25-35$ & $P$-value & \\
& Above 35 & 0.001 & Sig. \\
$25-35$ & $<25$ & 0.116 & Ns. \\
& Above 35 & 0.001 & Sig. \\
Above 35 & $<25$ & 0.137 & Ns. \\
& $25-35$ & 0.116 & Ns. \\
& Dependent Variable: Iron & Ns. \\
\hline Trimester & Trimester & $P$ value & \\
\hline First & Second & 0.657 & Ns. \\
& Third & 0.547 & Ns. \\
Second & First & 0.657 & Ns. \\
& Third & 0.864 & Ns. \\
Third & First & 0.547 & Ns. \\
& Second & 0.864 & Ns. \\
& & &
\end{tabular}

reduces its negative effects (Allen, 1997; Martins et al., 2009). In the present study, the measurements of serum iron concentration are assessed in the pregnant women after iron supplement implementation at the time of first, second, and third trimester of gestation to observe the prevalence of iron deficiency among them. Iron supplementation during pregnancy plays a key role in reduction of serum iron deficiency and preventing maternal morbidity and mortality.

The current study found that the percentage of serum iron deficiency were high in the first trimesters at different age groups and low in the second and third trimesters. This is in agreement with a study done previously in Baghdad province by AL-Shawi and his team, 2018, have observed that percentage of anemia between pregnant women in the first trimester is higher than pregnant women during second and third trimester (Razzak and Shawi, 2018) and in the same way, there is consistent with reports that show serum iron concentration change during pregnancy in Caucasian, Tariah, and Filipino (Alday et al., 2015; AmahTariah et al., 2011).

The results of this study are demonstrated that the concentration of serum iron in supplemented-pregnancy during the first, second, and third trimester of gestation, while, statistically not significant manner were observed in the values of serum iron concentration level in different ages among the three trimesters of pregnancy compared to minimum-maximum serum iron $\mu \mathrm{g} / \mathrm{dl}$. Similar to our results are observed in the literature. VanderJagt et al., 2007 observed a statistically not significant change in serum concentration of iron among trimesters (Vanderjagt et al.,
2007), but increase and/or decreases the level of serum iron concentration, depending on the maternal diet (De Sá et al., 2015).

The age of the pregnant women in this study was separated into three groups $(<25$ years, $25-35$ years, and above 35 years). The study showed, there is a statically significant difference observed in concentration of serum iron levels of those women aged $<25$ and between 25 and 35 years of age among three trimesters equal to 0.001 . Noteworthy, this variable between two aged groups as well remains not effected as the $P$-value for this maximalist change is not statistically significant. In the same way, this study agreed with Abdul-Fatah et al. observed that variable between two aged groups $(<25-35)$ were related to education and living area of life (Abdul-Fatah et al., 2018). Furthermore, hemoglobin concentration is significantly correlated with gestational age (Vanderjagt et al., 2007). While, according to results of this study, there is not statically significant difference in serum iron concentration between above 35 aged group and ( $<25$ and/or 25-35) years of age. As a result, in this study no relationship between age and anemia was observed.

\section{CONCLUSIONS}

The current study concluded that the percentage of serum iron among Sulaimani city iron supplemented pregnant women was high compared to other governorate or compared to other countries. Age of the women considered the risk factors of iron deficiency among supplemented pregnant women however; pregnancy trimesters had no effects on serum iron level.

\section{REFERENCES}

Abdul-Fatah, B. N., R. M. Murshid and T. E. Ahmed. 2018. Assessment of iron deficiency anemia (IDA) and dietary pattern among pregnant women in Baghdad city, Iraq. J. Pharm. Sci. Res. 10(9): 2279-2284.

Aguree, S. and A. D. Gernand. 2019. Plasma volume expansion across healthy pregnancy: A systematic review and metaanalysis of longitudinal studies. BMC Pregnancy Childbirth. 19: 1-11.

Ajepe, A. A., K. Sharafadeen, O. Id, I. Sekumade, E. S. Daramola, M. O. Beke, O. ljasan, O. F. Olowoselu and B. B. Afolabi. 2020. Prevalence and foetomaternal effects of iron deficiency anaemia among pregnant women in Lagos, Nigeria. PLoS One. 15(1): e0227965.

Alday, A., G. Giselle, L. Agahan, K. M. C. Africa, D. Marie, M. Jennifer, F. David, A. Cruz, E. Dyogi, R. Galutera, C. G. Gamboa, C. L. Hamada, M. G, Jaucian, T. L. Layugan, R. Rex, R. R. Samala, M. G. Santos, O. Segui, S. Seno, T. Y. Torres, H. L. Trinidad, M. T. Verano and M. Lean. 2015. A preliminary determination levels in normal filipino pregnant thansferrin of pregnancy women in the three thimesters. Acta Med. Philip. 
26(4): $120-126$.

Allen, L. H. 1997. Pregnancy and iron deficiency : Unresolved issues. Nutr Rev. 55(4): 91-101.

Amah-Tariah, F. S., S. O. Ojeka and D. V. Dapper. 2011. Haematological values in pregnant women in Port Harcourt, Nigeria II: Serum iron and transferrin, total and unsaturated iron binding capacity and some red cell and platelet indices. Niger. J. Physiol. Sci. 26(2): 173-178.

De Sá, S. A., E. Willner, T. Aguiar, D. Pereira, V. R. de Souza, G. T. Boaventura and V. B. de Azeredo. 2015. Original/pediatría anemia in pregnancy : Impact on weight and in the development of anemia in newborn. Nutr. Hosp. 32(5): 2071-2079.

WHO. Guideline: Daily iron and folic acid supplementation in pregnant women. Geneva, World Health Organization, 2012.

Juul, S. E., J. Derman and M. Auerbach. 2019. Perinatal iron deficiency : Implications for mothers and infants. Neonatology. 115: 269-274.

Kumar, A., A. K. Rai, S. Basu, D. Dash and J. S. Singh. 2014. Cord Blood and Breast Milk Iron Status in maternal anemia. Pediatrics. 121(3): e673-e677.

Martins, S., S. Logan and G. Lee. 2009. Iron therapy for improving psychomotor development and cognitive function in children under the age of three with iron deficiency anaemia. Cochrane
Database Syst Rev. 2013(6): CD001444.

Peña-Rosas, J. P. and F. E. Viteri. 2009. Effects and safety of preventive oral iron or iron + folic acid supplementation for women during pregnancy. Cochrane Database Syst Rev. 4: CD004736.

Razzak, A. and J. A. Shawi. 2018. Study the incidence and types of anemia in pregnant women in baghdad province. J. Univ. Anbar Pure Sci. 6(1): 3.

Terefe, B., A. Birhanu, P. Nigussie and A. Tsegaye. 2015. Effect of maternal iron deficiency anemia on the iron store of newborns in Ethiopia. Anemia. 2015: 8-11.

Tran, T. D., B. Biggs, T. Tran, J. A. Simpson, S. Hanieh, T. Dwyer and J. Fisher. 2013. Impact on infants' cognitive development of antenatal exposure to iron deficiency disorder and common mental disorders. PLoS One. 8(9): 1-9.

Vanderjagt, D. J., H. S. Brock, G. S. Melah, A. U. El-Nafaty, M. J. Crossey and R. H. Glew. 2007. Nutritional factors associated with anaemia in pregnant women in Northern Nigeria. J. Health Popul. Nutr. 25(1): 75-81.

Yakoob, M. Y. and Z. A. Bhutta. 2011. Effect of routine iron supplementation with or without folic acid on anemia during pregnancy. BMC Public Health. 11(3): S21. 